\title{
COOLING LOAD ANALYSIS IN CLASSROOMS: A CASE STUDY IN FEDERAL UNIVERSITY OF SAN FRANCISCO VALLEY, BRAZIL
}

GOMES, Isabella Gonçalves de Aguiar ${ }^{1}$ CASTRO SILVA, José ${ }^{2}$

SUMMARY: This paper aims to calculate the cooling thermal load of 32 classrooms of Federal University of San Francisco Valley, located in Petrolina, Brazil, using the software EnergyPlus ${ }^{\mathrm{TM}}$ and the graphic user interface OpenStudio ${ }^{\circledR}$. OpenStudio ${ }^{\circledR}$ also has a plug-in to Sketchup, which allowed the construction of a tridimensional energetic model of the considered building. EnergyPlus ${ }^{\mathrm{TM}}$ takes into account climatic conditions, schedules, construction materials and internal loads such as people occupancy, lightning and electric equipment, and so it calculates the cooling thermal load. Then the cooling thermal load of a single classroom was calculated by three traditional methods described in the literature, and the results were compared with the one from EnergyPlus ${ }^{\mathrm{TM}}$. The results of the 32 classrooms differed according to the building story where the classrooms are located, the orientation of walls and windows in each classroom, as well as the internal loads. Regarding the single classroom analysis, the component loads of each method were compared. For some components, such as lightning and electrical equipment, the results were very similar among all the methods, what was not verified for other componentes, such as the infiltration and solar gains. The overall cooling load results from the traditional methods were similar, but too high compared with the results from EnergyPlus ${ }^{\mathrm{TM}}$.

Keywords: Climatization. Heat gains. EnergyPlus. OpenStudio

RESUMO: Este trabalho tem por objetivo calcular a carga térmica de resfriamento de 32 salas de aula da Universidade Federal do Vale do São Francisco, em Petrolina, Brasil, utilizando o software EnergyPlus ${ }^{\mathrm{TM}}$ e a interface gráfica de usuário OpenStudio ${ }^{\circledR}$. O OpenStudio ${ }^{\circledR}$ possui ainda um plug-in para o SketchUp, o que permitiu a construção de um modelo energético tridimensional do edifício considerado. O EnergyPlus ${ }^{\mathrm{TM}}$ leva em consideração as condições climáticas, horários de funcionamento, materiais de construção e cargas internas (como ocupação, iluminação e equipamentos elétricos), para em seguida calcular a carga térmica. Em seguida, a carga térmica de uma única sala de aula foi calcula por três métodos tradicionais descritos na literatura, e tais resultados foram comparados com o valor obtido pelo EnergyPlus ${ }^{\mathrm{TM}}$. O resultado das 32 salas de aula variou de acordo com o andar do edifício, a orientação das paredes e janelas em cada sala, bem como com as cargas internas. Para essa sala de aula escolhida, foram comparados os components da carga térmica obtidos com cada método. Alguns components, como iluminação e equipamentos elétricos, apresentaram resultados semelhantes em todos os métodos, o que não foi observado com outros components, como infiltração e ganhos solares. O resultado de carga térmica total dos métodos tradicionais foi muito semelhante, mas elevado em comparação com os resultados do EnergyPlus ${ }^{\mathrm{TM}}$.

Palavras-chave: Climatização. Carga Térmica. EnergPlus. OpenStudio

\section{INTRODUCTION}

Petrolina is located in the Brazilian Northeast, in Pernambuco state, and is known nationally for its high temperatures and scarce rains all year round. According to Teixeira (2010), from 1965 to 2009 the average monthly temperature in Petrolina varied between $21.4^{\circ} \mathrm{C}$ and $28^{\circ} \mathrm{C}$, being June and July the coolest months and October and November the hottest. The relative humidity in Petrolina oscillates between $66 \%$ and $73 \%$ in April, the wettest month and the end of the rain season, and remains under 55\% in September and October.

\footnotetext{
${ }^{1}$ Bacharel em Engenharia Mecânica. Universidade Federal do Vale do São Francisco

${ }^{2}$ Professor de Engenharia Mecânica da Universidade Federal do Vale do São Francisco
} 
Due to Petrolina's climate conditions, the climatisation of the classrooms in the Federal University of San Francisco Valley (UNIVASF) is a factor of major impact in the welfare of students, professors and

servants, and has been provided since the University was founded. Currently this climatisation is guaranteed by split sytems used in all classrooms.

Given the importance of the thermal comfort at UNIVASF, this paper aims to calculate the cooling thermal load of the classrooms, using the software EnergyPlus ${ }^{\mathrm{TM}}$. It is really important for a climatisation project that the cooling load be estimated with a high level of precision, in order to avoid equipment under or oversizing. In this sense, the use of EnergyPlus ${ }^{\mathrm{TM}}$ can provide better results, due to its capability of perform complex calculations that would be nearly impossible to do without a computational tool.

Although all the advantages of EnergyPlus ${ }^{\mathrm{TM}}$, in the practice of engineering still remains the use of traditional calculation methods, described in the literature and based in pre-determined tables and coefficients, which always depend on the location considered in the climatisation project. Such methods have long been used by HVAC engineers, are trustworthy among professionals and have been performing reliable results.

The objective of this paper is to perform the cooling load calculation with EnergyPlus ${ }^{\mathrm{TM}}$ for 32 classrooms and then pick a single classroom and analyze three methodologies for cooling load calculation available in the literature and compare them with the method of EnergyPlus ${ }^{\mathrm{TM}}$.

\section{MATERIAL AND METHOD}

\section{Computational tool}

The software used to calculate the cooling load was EnergyPlus ${ }^{\mathrm{TM}}$, developed by the National Renewable Energy Laboratory (NREL) of USA Department of Energy (DOE). Crawley et al (2000) state that EnergyPlus ${ }^{\mathrm{TM}}$ combines the best characteristics and resources of its predecessors, BLAST and DOE2, and even presents new resources. EnergyPlus ${ }^{\mathrm{TM}}$ is a simulation software, and does not have a graphic user interface. Therefore, graphic user interface used was OpenStudio®, which is also developed by NREL and contains a plug-in for Sketchp, turning the modelling process easier.

\section{Modelling and Simulation}

Each classroom corresponds to a thermal zone, in a total of 32. In OpenStudio® were inserted all the data needed for the simulation: climate conditions of Petrolina (available in the EnergyPlus ${ }^{\mathrm{TM}}$ 's website and based in the data collected by the weather station of Petrolina's Airport), the construction materials used in the building, the schedules, the occupation rate (the amount of people in each thermal zone), the heat released by these people and the power of the lamps and the electric equipment of the rooms. The infiltration rate was calculated by EnergyPlus ${ }^{\mathrm{TM}}$, and was admitted a renewal rate of outdoor air according to the Brazilian National Agency of Health Surveillance's (ANVISA) resolution (RE $n^{\circ} 9$ of 16th January of 2003).

\section{Cooling load calculation methods}


Three methods for calculating the cooling load were choose in the literature to be compared with EnergyPlus ${ }^{\mathrm{TM}}$ : Springer Carrier's Air Conditioner Guide (1999), Helio Creder's method (2009) and Ennio

Cruz da Costa's method (1991). All these methods are largely used in Brazil, and all of them estimate the cooling thermal load counting the heat gains due to conductivity (sensible heat), solar incidence (sensible heat), people (sensible and latent heat), lightning (sensible heat), electric equipment (sensible and latent heat), infiltration (sensible and latent heat) and ventilation (sensible and latent heat)

\section{RESULT AND DISCUSSION}

\section{Cooling load results from EnergyPlus ${ }^{\mathrm{TM}}$}

For each thermal zone, EnergyPlus ${ }^{\mathrm{TM}}$ found the peak cooling load, which occurs in 21th February. The following figures show the peak cooling load of each thermal zone, as well as the time of the day in which it occurs. The building's total cooling load was 86,41 TR. In Figure 1 (which represents the classrooms in the first story), the blue arrow indicates the thermal zone 2 , the one chosen to compare the literature methods and EnergyPlus ${ }^{\mathrm{TM}}$ 's method. Figure 2 represents the classrooms in the second story of the building.

Figure 1: Peak cooling load results for the first story classrooms

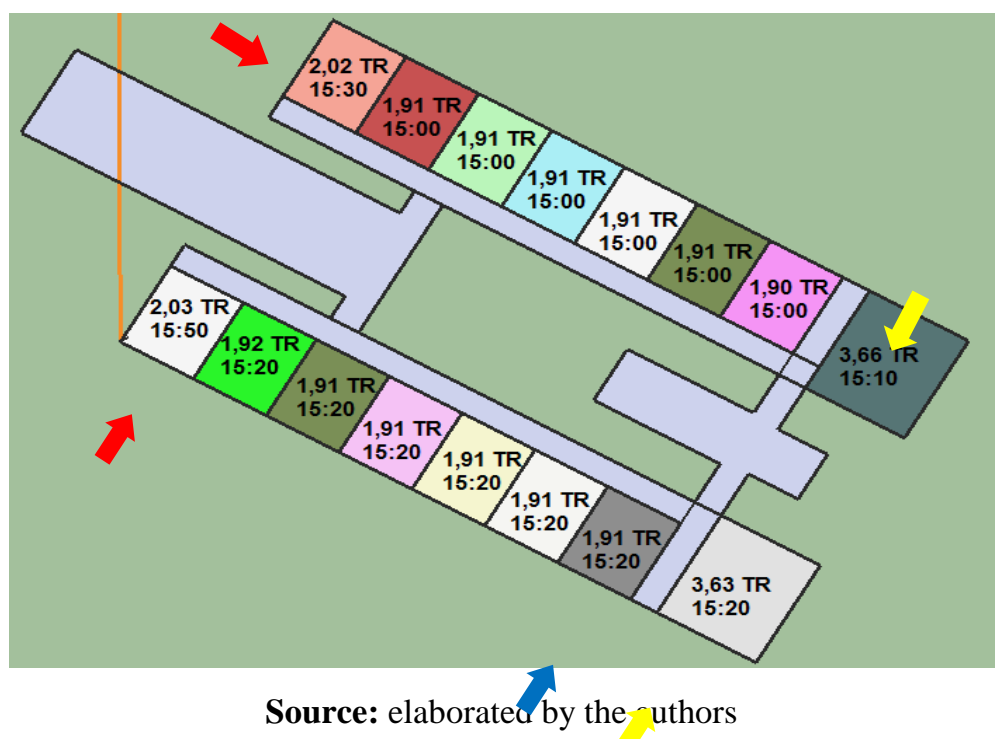

Figure 2: Peak cooling load results for the second story classrooms 


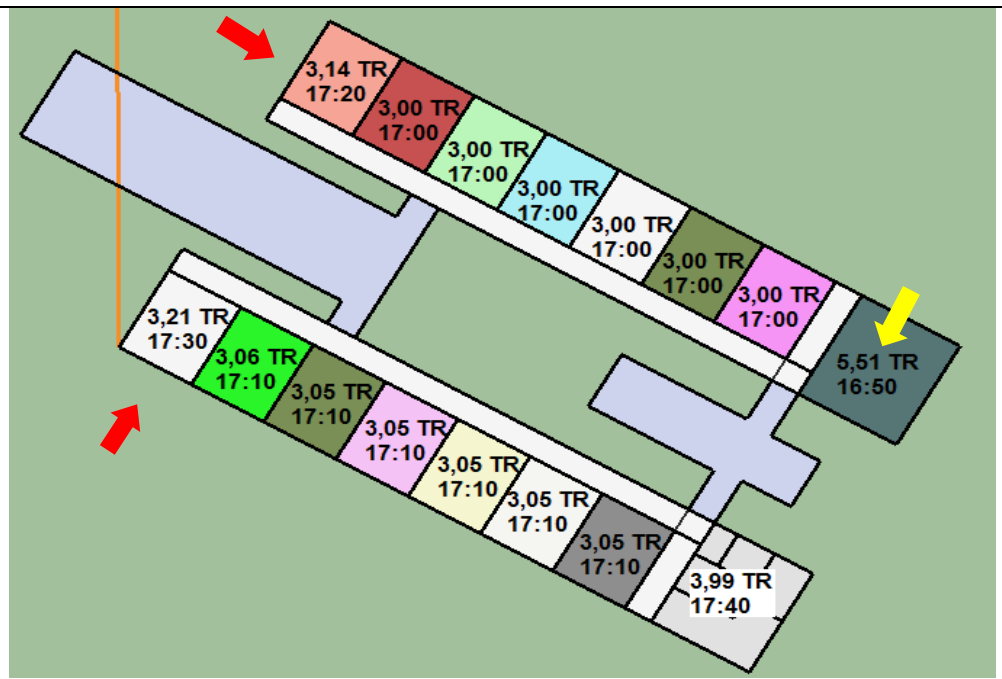

Source: elaborated by thr authors

From the figures above, it is possible to notice that the classrooms in the second story presented a higher peak cooling load than the classrooms in the first story. It happened because the classrooms in the second story have contact with the roof, what increases the conduction and solar gains.

The bigger thermal zones (indicated by the yellow arrows), that are classrooms dedicated to research groups and the E-learning Department $(\mathrm{SEaD})$, presented a higher peak cooling load when compared to the others due to the larger wall surfaces (which increase the conduction gains), the larger window surfaces (which increase the solar gains) and the higher number of occupants and lightning (which increases the internal gains). The following table shows the total room area, the wall and window area, the number of occupants and the lightning of the ordinary classrooms, the research groups' classrooms and SEaD.

Table 1: Thermal zones characteristics

\begin{tabular}{cccc}
\hline Space & $\begin{array}{c}\text { Ordinary } \\
\text { classrooms }\end{array}$ & $\begin{array}{c}\text { Research groups } \\
\text { classrooms }\end{array}$ & SEaD \\
\hline $\begin{array}{c}\text { Area }\left[\mathrm{m}^{2}\right] \\
\text { Volume }\left[\mathrm{m}^{3}\right]\end{array}$ & 67,12 & 116,8 & 116,8 \\
Gross wall area [m²] & 235,29 & 409,37 & 409,37 \\
Glass window area & 9,62 & 111,64 & 111,64 \\
$\quad\left[\mathrm{~m}^{2}\right]$ & 26,26 & 26,26 \\
Lightning [W] & 7200,03 & 12528,18 & 12528,18 \\
Number of & 51 & 88 & 20 \\
occupants & & & \\
\hline
\end{tabular}

Source: elaborated by the authors 
In the ordinary classrooms, which have the same area, number of occupants and lightning, the differences occurred in the thermal zones indicated by the red arrows in Figures 1 and 2. In these cases, the differences in the peak cooling load were verified because the indicated classrooms have a northwestoriented wall (that the other classroom do not have), which increases the solar gains during the afternoon

\section{Comparison between EnergyPlus ${ }^{\mathrm{TM}}$ and three literature methods}

To compare EnergyPlus ${ }^{\mathrm{TM}}$ 's results with other three methods from the literature, the thermal zone 2 was choose. The three methods considered were Creder's (2009), Costa's (1991) and Carrier's (1999). In the comparison, have been analyzed the heat gains due to conduction, solar incidence, peope, lightning, electric equipment and infiltration.

It is important to notice that EnergyPlus ${ }^{\mathrm{TM}}$ 's algorithms calculate the total cooling load, and gives an estimation of each sensible heat gain component (not included the latent heat gains).

Table 2 shows the comparison among all methods for the conduction heat gains. Creder (2009), Carrier (1999) and Costa (1991) present the same equation for conductive heat gains, varying only the heat transmission coefficient of the materials, which are defined by each method. It is important to notice that Carrier (1999) is the only method that has not presented the thermal conductivity of glass. On the other hand, EnergyPlus ${ }^{\mathrm{TM}}$ uses the conduction transfer functions (CTF), which are a much more sophisticated method for calculating the conductive heat gains.

Table 2: Comparison of the heat gains due to conduction

\begin{tabular}{cc}
\hline Method & $\begin{array}{c}\text { Heat gain due to } \\
\text { conduction }(\mathbf{k c a l} / \mathbf{h})\end{array}$ \\
\hline Carrier & 1641,26 \\
Creder & 1733,18 \\
Costa & 2208,76 \\
EnergyPlus & 1249,67 \\
\hline
\end{tabular}

Source: elaborated by the authors

Table 03 compares the heat gains due to solar incidence. Carrier (1999) did not present any methodology to calculate the heat gains due to solar incidence.

Table 3: Comparison of the heat gains due to solar incidence

\begin{tabular}{cc}
\hline Method & $\begin{array}{c}\text { Heat gain due to solar } \\
\text { incidence }(\mathbf{k c a l} / \mathbf{h})\end{array}$ \\
\hline Carrier & 0,00 \\
Creder & 4025,99 \\
\hline
\end{tabular}




$\begin{array}{cc}\text { Costa } & 2796,52 \\ \text { EnergyPlus } & 539,76\end{array}$

Source: elaborated by the authors

Table 4 compares the heat gains due to people occupancy. As said before, EnergyPlus ${ }^{\mathrm{TM}}$ does not present the latent heat in the peak cooling load components. Creder (2009), Carrier (1999) and Costa (1991) present the values of the heat emitted by people, depending on the activity level. The fraction of sensible and latent heat is determined by the room temperature, and each method presents those values. In EnergyPlus $^{\mathrm{TM}}$, the user defines the amount of heat emitted by a single person and the software automatically calculates the sensible and the latent fraction.

Table 4: Comparison of the heat gains due to people

\begin{tabular}{|c|c|c|}
\hline \multirow[t]{2}{*}{ Method } & \multicolumn{2}{|c|}{$\begin{array}{l}\text { Heat gain due to people } \\
\qquad(\mathrm{kcal} / \mathrm{h})\end{array}$} \\
\hline & Sensible & Latent \\
\hline Carrier & 3060,00 & 2040,00 \\
\hline Creder & 3372,10 & 1794,00 \\
\hline Costa & 3060,00 & 2040,00 \\
\hline EnergyPlus & 2730,40 & 0,00 \\
\hline
\end{tabular}

Source: elaborated by the authors

The results for the heat gains due to lighting are compared in Table 5.

Table 5: Comparison of the heat gains due to lightning

\begin{tabular}{cc}
\hline Method & $\begin{array}{c}\text { Heat gain due to } \\
\text { lightning }(\mathbf{k c a l} / \mathbf{h})\end{array}$ \\
\hline Carrier & 774,00 \\
Creder & 619,20 \\
Costa & 619,20 \\
EnergyPlus & 619,24 \\
\hline
\end{tabular}

Source: elaborated by the authors

The heat gains due to electric equipment are shown in Table 6. The results from all methods were the same. That is because in all methods the heat emitted by the electric equipment is calculated by multiplying the total power by a factor of 0.86 . 
Table 6: Comparison of the heat gains due to electric equipment

\begin{tabular}{cc}
\hline Method & $\begin{array}{c}\text { Heat gain due to electric } \\
\text { equipment }(\mathbf{k c a l} / \mathbf{h})\end{array}$ \\
\hline Carrier & 215,00 \\
Creder & 215,00 \\
Costa & 215,00 \\
EnergyPlus & 215,00 \\
\hline
\end{tabular}

Source: elaborated by the authors

Table 7 presents the heat gains due to infiltration. Carrier (1999) did not present any methodology to calculate the heat gains due to infiltration, and also did not provide the data needed to calculate the gains due to ventilation in this specific case (classrooms). In this table, EnergyPlus ${ }^{\mathrm{TM}}$ counts for both infiltration and ventilation heat gains, while all other methods count for infiltration heat gains only.

Though Creder (2009) presented a methodology to calculate the heat gains due to ventilation, it has resulted in 44,52 TR due to ventilation only, while the summation of all other heat gains in this method has resulted in 4,42 TR. Because its result was absurdly high, the gain due to ventilation was neglected.

Least, Costa (1991) did not present the data needed to calculate the heat gain due to ventilation.

Table 7: Comparison of the heat gains due to infiltration

\begin{tabular}{ccc}
\hline Method & \multicolumn{2}{c}{ Heat gain due to infiltration } \\
& \multicolumn{2}{c}{ (kcal/h) } \\
\cline { 2 - 3 } & Sensible & Latent \\
Carrier & 0,00 & 0,00 \\
Creder & 653,89 & 946,47 \\
Costa & 653,89 & 946,48 \\
EnergyPlus & 5917,81 & 0,00 \\
\hline
\end{tabular}

Source: elaborated by the authors

The final cooling load obtained by each method is reported in Table 8. The final cooling load for EnergyPlus $^{\mathrm{TM}}$ is the peak cooling load presente by the software as the final result, not the summation of the sensible heat gain components.

Table 8: Comparison of the cooling load results

\begin{tabular}{cc}
\hline Method & Cooling load (TR) \\
\hline Carrier & 2,56 \\
Creder & 4,42 \\
Costa & 4,15 \\
\hline
\end{tabular}




\begin{tabular}{ll}
\hline EnergyPlus $^{\mathrm{TM}}$ & 1,91 \\
\hline
\end{tabular}

Source: elaborated by the authors

\section{CONCLUSION}

When compared to the methods described in the literature, the results from EnergyPlus ${ }^{\mathrm{TM}}$ were the lowest among all. That is probably due to the fact that EnergyPlus ${ }^{\mathrm{TM}}$ calculates the cooling load for each hour of the year, taking into consideration transient heat exchanges and contributes from previous time steps, which is not done by the other methods. The other methods, for instance, use pre-determined coefficients and values, which are actually approximations of complex calculations. That can lead to uncertainties that affect the final results. In this sense, EnergyPlus ${ }^{\mathrm{TM}}$ can provide more accurate results, helping to avoid over dimensioning.

A frailty of EnergyPlus ${ }^{\mathrm{TM}}$ is that the heat gain components are only estimated. Moreover, the latent heat gains are not present in these components. That can make harder to the designer to analyze the heat gains in particular, which could be helpful to evaluate the impact of each heat source in the final cooling load.

\section{REFERENCES}

COSTA, E.C.da. Física aplicada à construção: conforto térmico. 4.ed. São Paulo: Edgar Blücher, 1991.

CRAWLEY, D.B.et al. EnergyPlus: Energy simulation program. ASHRAE Journal, abril de 2000.

CREDER, H. Instalações de ar condicionado. 6.ed. LTC: Rio de Janeiro, 2009.

MANUAL DO AR CONDICIONADO. Carrier Air Conditioning Co. Marcombo SA, 1999.

TEIXEIRA, A. H. de C. Informações agrometeorológicas do polo Petrolina, PE/Juazeiro, BA - 1963 a 2009. Petrolina: Embrapa Semiárido, 2010. 